\title{
A Legal Analysis on the Construction of Chinese Monetary Union in Four-Regions of China across the Straits
}

\author{
Hu Ren ${ }^{1 *}$, Yanwei Yao \\ ${ }^{1}$ School of Law, East China University of Science and Technology, Shanghai, China \\ ${ }^{2}$ GRANDALL Law Firm (Shanghai), Shanghai, China \\ Email: *yimhao@hotmail.com, yaoyanwei@grandall.com.cn
}

How to cite this paper: Ren, H., \& Yao, Y. W. (2019). A Legal Analysis on the Construction of Chinese Monetary Union in Four-Regions of China across the Straits. Beijing Law Review, 10, 992-1011. https://doi.org/10.4236/blr.2019.104053

Received: August 19, 2019

Accepted: September 8, 2019

Published: September 11, 2019

Copyright (๑) 2019 by author(s) and Scientific Research Publishing Inc. This work is licensed under the Creative Commons Attribution International License (CC BY 4.0).

http://creativecommons.org/licenses/by/4.0/ (c) (i) Open Access

\begin{abstract}
As a united country, there are four currencies in China, including Mainland, Hong Kong, Macao and Taiwan (hereinafter referred to as "the Four Regions"). The realization on the construction of Chinese Monetary Union in the Four Regions is a crucial step to realize the strategy of the RMB internationalization, and it will make great progress in the promotion of China's economy. The similarity in economic structure and the high dependence on trade make it feasible to construct a Chinese Monetary Union among the Four Regions, however, challenges from legal, political and economic problems still exist. The theory of optimum currency area and the experience and practice of European Currency Union will provide a proper basic theory and the best model to construct the Chinese Monetary Union. While Chinese Monetary Union cannot be realized overnight, it requires a gradual promotion by stages as well as a thorough legal supervision by providing guarantees. From the respect of strategic planning, monetary integration between Hong Kong and Macao would be the first step, then turn to realize the integration between Hong Kong, Macao and Mainland China, monetary integration within the four regions shall be realized at the last stage. In addition, from the perspective of constructing an effective economic and legal system, it is necessary to simultaneously promote the construction of unified institutions, develop the offshore RMB market, construct the RMB fund, exchange rate evaluation system and other economic systems, as well as the construction of relevant legal systems, so as to guarantee the effectively operation of the Chinese Monetary Union.
\end{abstract}

\section{Keywords}

Chinese Monetary Union, European Union, Four Regions of China 


\section{Introduction}

Over the past years, domestic and foreign circumstances faced by China in its development have been complicated and challenging. The road to global economic recovery has been rough, with many ups and downs, and the performance of the major economies has been divergent. Downward pressure on China's economy has continued to mount, and China has faced an array of interwoven difficulties and challenges. The growth rate was steady and improved. China's GDP has reached 63.6 trillion RMB, an increase of $7.4 \%$ over the previous year in 2014 ( $\mathrm{Li}, 2015)$ and 67.7 trillion RMB with an increase of $6.9 \%$ in 2015 ( $\mathrm{Li}, 2016$ ), making China one of the fastest-growing major economies in the world.

China has been effectively implementing proactively fiscal policies and prudent monetary policies. China has increased targeted tax reductions, reduced fees across the board, extended the coverage of tax relief policies to benefit small and micro businesses more, and expanded the trials to replace business tax with VAT to cover more industries. China has sped up the process of making budgetary funds available for fiscal expenditures and put surplus budgetary funds to good use. By flexibly utilizing monetary policy instruments, making targeted cuts to required reserve ratios, carrying out targeted re-lending, and making asymmetric interest rate cuts, China stepped up supports for weaker areas in economic and social development. Increases in loans made to small and micro businesses, and loans for agriculture, rural areas, and farmers, outdid the average increase in loans overall by 4.2 and 0.7 percentage points respectively in 2014. At the same time, regulation of the financial sector was improved and regional and systemic risks were forestalled ( $\mathrm{Li}, 2015)$. In 2015, Momentum was created for reform and development through opening up. The RMB was included in the IMF's Special Drawing Rights basket. The Asian Infrastructure Investment Bank was officially inaugurated, and the Silk Road Fund opened for business. China signed free trade agreements with the Republic of Korea and Australia, respectively, and signed the Protocol to Amend the Framework Agreement on Comprehensive Economic Cooperation between China and Association of Southeast Asian Nations. Progress was made in the Silk Road Economic Belt and 21st Century Maritime Silk Road Initiative (the Belt and Road Initiative), the pace of China's industrial-capacity cooperation with other countries was stepped up, and breakthroughs were made in China's export of high-speed railway and nuclear power equipment (Li, 2016).

With the continuous deepening of the world economy cooperation and the regional financial integration, regional monetary integration has become an important measure to promote the development of regional economy, enhancing the economic strength and preventing the financial crisis. Since the 1970s, there have emerged a large number of regional monetary organizations such as West African Monetary Union, Central African Monetary Union, Arabian Monetary Union and European Monetary Union, among which the practice of the Euro- 
pean Monetary Union is the most successful one and can be used for reference. The emergence of regional monetary union indicates the transformation from "one country, one currency" to "one market, one currency". In this context, China, as a sovereign state, however, has four currencies in the Four Regions in China's mainland and Taiwan Island, which is a huge obstacle for the economic development of Greater China. The realization of the integration of currencies in the Four Regions is crucial to the financial integration and also an experience reference for Asian Monetary Integration.

\section{Is It Necessary and Possible to Construct the CMU?}

\subsection{The Necessity of Constructing the CMU}

Regional monetary organizations such as West African Monetary Union, Central African Monetary Union, Arabian Monetary Union and European Monetary Union are prevalent within different countries to achieve more economic benefits. West African Monetary Union was established in 1962, in which there are unified currency and central bank. Central African Monetary Union was established on the base of Central African Economic and Customs Union (UDEAC) in 1964. In March 1994 the six UDEAC leaders signed a treaty for the establishment of an Economic and Monetary Community of Central Africa (CEMAC), which was to promote the process of sub-regional integration within the framework of an economic union and a monetary union (Zhu, 2008). Firstly, it reduces the efficiency of monetary transaction and increases the transaction cost to have different currencies in one country. Areas in a monetary union can gain reductions in trading costs in addition to the elimination of exchange-rate volatility. Secondly, the current situation of "one country, four currencies" increases the potential market crisis and weakens its resistance to financial crisis. The managed floating exchange rate system is applied to RMB, while the pegged rate system to US dollar is applied to Hong Kong dollar and Macao pataca, which makes their regional economic goals subject to America's economic goal, being negative to the economic development of Hong Kong and Macao (Xiong \& Liu, 2004). Thirdly, more and more countries seek monetary integration in some certain areas according to the principle of "one market, one currency". Such as the European Monetary Union which has a lot of experience in this area. And Asia is also seeking monetary integration now, but there is a long way to go. So it is necessary to construct monetary union in China no matter from political or economic perspective. Fourthly, the main cost of the monetary cooperation is that member state may lose its respective monetary policy autonomy. However, with strengthening regional economic integration level, unified regional monetary policies can be made to promote the regional economic development and improve the welfare of the member states. In the practice of the German Monetary Union, the currency of West Germany which had much more economic power was chosen to be used. Meanwhile, East Germany has gained a lot of benefits from this currency union. A stable monetary environment was created, faci- 
litating the economic development in the long run after the unification of Germany. In some extent, it suggests that the issue of whether two countries (or regions) constitute an optimum currency area ultimately is a political one (De Grauwe, 1992).

The Chinese Monetary Union in the Four Regions is essential to the regional internationalization of RMB and will promote the internationalization of RMB. It will be beneficial to the economy of the greater China. Unified monetary may reduce transaction costs and exchange risk as well as strengthen microcosmic economic vitality.

\subsection{The Feasibility of Constructing the CMU}

1) Similarity in economic structure

Similarity in economic development and structure are important premises for the construction of a currency union. Because that an economic shock is considered to be symmetric to the countries in the currency union if the economic development level and the economic structure of the state and region in the currency union are similar, in which countries can adopt same or similar monetary policy to offset, thereby there is no need to reserve independent monetary policy (Jager \& Hafner, 2013).

In terms of this condition, the economic scale and economic aggregate of Mainland China, Hong Kong, Macao and Taiwan are different, while comparing the Per Capita GDP of the Four Regions, the GDP of Mainland China is much more smaller than the other three areas, which indicates that Mainland China still fall considerably short of them in the economic development level. In terms of the economic growth rate, the economic development of Mainland China is relatively stable, while Hong Kong and Macao are free port zones which are vulnerable by the international economic fluctuation. ${ }^{1}$ This indicates that although the construction of the Chinese Monetary Union in Mainland China, Hong Kong, Macao and Taiwan has its foundation, there still are certain difficulties along with.

2) Openness and Intraregional trade

From the perspective of economic openness, it is another criterion to inspect whether there are conditions to conduct monetary cooperation. For a highly open economy, adopting a floating exchange rate to adjust international balance of payment has limited effectiveness. For example, if the international balance of payment is adjusted by adopting the approach of keeping their exchange rates low, the price of the import commodity will rise accordingly first and then all the commodity will rise too. While if the increase of the price is limited, it could cause demand contraction and rising unemployment. Secondly, because of the

\footnotetext{
${ }^{1}$ According to China Statistical Yearbook 2015, the Per Capita GDP of Mainland China in 2014 is 7590.8 US dollar, Hong Kong is 40,170 US dollar, Macao is 89,333 US dollar, and Taiwan is 23,390 US dollar. The economic growth rate of Mainland China is 7.4\%, Hong Kong is 2.5\%, Macao is $-0.4 \%$, and Taiwan is $6.2 \%$. See STATISTICAL YEARBOOK OF CHINA, National Bureau of Statistics of the People's Republic of China, http://www.stats.gov.cn/tjsj/ndsj/.
} 
"monetary illusion", people may demand for higher nominal wages to maintain the value of real wages and offset the devaluation effect after the devaluation of the currency. Thirdly, the higher the openness is, the higher the dependence on imported goods, the smaller the elasticity of demand is and the larger the relative demand of adjusting rate is (Zhu \& Chen, 2004). So relatively closed currency union should be constructed among highly open economy, which is more beneficial to realize the macroeconomic target.

After the reform and opening up policy of Mainland China, the Four Regions have achieved sustained and rapid economic development and considerably improved its overall strength. With continuously improving economic openness, the Four Regions are mutually complementary and beneficial. ${ }^{3}$ The economic development level of Mainland China has always been kept in such range with its economic development. Hong Kong, Macao and Taiwan are all follow the way that economic open economies. If entrepot trade is taken into account, the economic openness of Hong Kong will be above $200 \%$, which strongly supports the construction of Chinese currency union.

3) High dependence on trade in Chinese Economic Area

Hong Kong, Macao and Taiwan have kept a close economic relationship with Mainland China. The trade volumes of the Four Regions within Chinese Economic Area account for large percent of their total foreign trade volume with steady improvement. This proves that Hong Kong, Macao and Taiwan have much economic dependence on Mainland China within Chinese Economic Area, especially Hong Kong and Macao, whose major region for merchandise imports and exports is the mainland of China. Macao imports from Hong Kong and the mainland of China in 2013 respectively for 10.5 billion and 26.41 billion. Hong Kong imports from the Mainland of China in 2013 for 40.607 billion and exports to the Mainland of China for 248 million. ${ }^{4}$ For Taiwan, economy and trade with Mainland China has been continuously improved. Currency union is needed for such intimate economic relationship to reduce transaction cost, facilitate transaction and improve economic relationship.

4) Degree of unemployment

In terms of unemployment rate, if the unemployment rate of a state is high in a single currency area, this state has the motivation to reduce the interest rate to stimulate economic development. Meanwhile, another state is suffering the pressure of currency inflation, thus there will be conflicts of economic policies between these two states (Zhu \& Chen, 2004). The similarity of unemployment rate of every state (region) in the currency union will directly affect the stability

\footnotetext{
2"Monetary illusion" was raised by Irving Fisher, an American economist. It refers that people only focus on the nominal value of the currency, while neglecting its actual purchasing power.

${ }^{3}$ According to China Statistical Yearbook 2015, the economic openness of the four regions in 2014 is as following: Mainland China is $41.54 \%$, Hong Kong is $349.88 \%$, Macao is $22.53 \%$, and Taiwan is 106.96\%. See STATISTICAL YEARBOOK OF CHINA, National Bureau of Statistics of the People's Republic of China, http://www.stats.gov.cn/tjsj/ndsj/. ${ }^{4}$ Ibid.
} 
of the currency after the construction of the currency union. ${ }^{5}$

\subsection{Finding}

According to the analysis on the data of economic development and the trade, investment and financial cooperation in the Four Regions, Mainland China has achieved impressive results and has been safe from the global financial crisis with stable economic development. Mainland China has played an important role in the Chinese Economic Area. Hong Kong, Macao and Taiwan rely heavily on the economy of Mainland China, which is the important prerequisite of the construction of the Chinese Monetary Union in the Four Regions. Upon the strong policy support of the economic cooperation agreements and with the similarity of some economic indicators among the Four Regions, it is feasible to construct a Chinese Monetary Union. Scholars have studied on the feasibility on construction of Chinese Monetary Union through VAR model on the data before 2008, drawing a conclusion that continuous economic development of Hong Kong, Macao, Taiwan and Mainland China are prompting the formation of a strong Chinese Economic Area and making the construction of Chinese Monetary Union feasible (Zhang, Sato, \& McAleer, 2008).

\section{What Are the Current Problems to Construct the CMU?}

\subsection{The Legal Problems}

The construction of Chinese Monetary Union needs both rational system and legal protection. Under the idea of "one country, two systems", Hong Kong and Macao have respective independent currency issuance system. There are People's Bank of China, Hong Kong Monetary Authority, Macao Monetary Authority and Bank of Taiwan in the Four Regions regulating and adjusting the respective currency policies. These four authorities are independent on its regulation, although some financial cooperation has been put forward within these authorities, including but not limit to the cooperation of the financial regulatory authorities in the areas of banking, securities, futures and insurances and the information sharing. However, if the currency union is constructed, necessary adjustments regarding to the currency, exchange rate and other economic social policies are lacked in the Four Regions, so laws are needed to avoid the conflicts in policies.

\subsection{The Political Problems}

Chinese Monetary Union in Mainland China, Hong Kong, Macao and Taiwan involves economic and trade relations and means that every party has to abandon the respective right to adopt monetary means to adjust the economy. For Hong Kong and Macao, they are the Special Administrative Region of the

${ }^{5}$ According to China Statistical Yearbook 2014, the unemployment rate of the four regions (2014) is as follows: Mainland China is $4.09 \%$, Hong Kong is $3.3 \%$, Macao is $1.7 \%$, and Taiwan is $4.0 \%$. See STATISTICAL YEARBOOK OF CHINA, National Bureau of Statistics of the People's Republic of China, http://www.stats.gov.cn/tjsj/ndsj/. 
people's Republic of China, enjoying the right of autonomy in a high level for years. The currency union will inevitably weaken or even deprive their autonomy in conducting their own currency policies.

The One-China principle has been evolved in the course of the Chinese people's just struggle to safeguard China's sovereignty and territorial integrity, and its basis, both de facto and de jure, is unshakable. However, considerable work still needs to be done in the reunification process. There still remains political divergence between Mainland China and Taiwan, in this situation, the economic interaction and monetary financial cooperation between Mainland China and Taiwan will be constrained. The political divergence will be a huge obstacle in the currency union process.

\subsection{The Economic Problems}

1) RMB is unfulfillment of the free exchange under capital account

A currency which can't realize the free exchange may have limited range of activity in the international market. With the deepening of the reform and opening of Mainland China's financial sector, the foreign exchange management regime of Mainland China gradually moves towards a market-oriented industrialization. At the present stage, financial market and financial regulation of Mainland China are still at a low level, having no condition to open the capital account for free exchange, so we still take strict control on the capital account. In 2013, the establishment of China (Shanghai) Pilot Free Trade Zone has realized that the open of RMB capital account go ahead in China (Shanghai) Pilot Free Trade Zone and then gradually realize the free exchange. The People's Bank of China emphasizes constantly that there is no schedule to realize the free exchange for RMB under the capital account. When to open the free exchange for RMB under the capital account depends on the development of the financial market and the level of financial regulation related to that in China (Wang, 2007).

2) Further economic exchange within the Four Regions

The flow of production factors and economic openness within the Four Regions has yet to be enhanced. The higher the degree of economic openness is, the greater the negative impact that a floating exchange rate will have on internal and external economic equilibrium, the better to construct or join into a common currency area. Although the Four Regions are making continuous efforts to eliminate the obstacles to trade and investment, which has huge promotion on the flow of the commodity and direct investment, the flow of other production factors such as the flow of personnel and capital are limited (Yan, 2001). The flow of these production factors represents the closer economic connection between the Four Regions.

\section{What's the Best Model to Construct the CMU?}

\subsection{Historical Models and Theories of Currency Integration}

1) Regional monetary cooperation system 
The definition of monetary integration can be divided into three kinds according to the cooperation degree of each country in the region (Zhu, 2007). One is regionalization of the dominant currency, the government of a country officially chooses the currency of another country to replace its own currency. For example, the dollarization in Latin American countries, Members within the area choose the dominated currency in the area and meanwhile abandon its own currency, realizing the regional monetary union. The second one is a regional currency alliance, which refers that the related countries make cooperation on some financial currency issues through legal documents (international agreement complied by the whole parties), such as African regional monetary cooperation. The third one is the currency area, the supreme form of currency integration, with the characteristic of fixed nominal exchange rate within the member states. For example, European monetary integration is a single currency monetary union, which realizes the single currency in certain area through deepening the cooperation on the respective economy and politics. In the optimum currency area, a dominated currency is regarded as a common base to the exchange rate. There is full and free convert between the dominated currency and the currencies of the member states, which means that the monetary policies rights of the member states will be weakened. There will be coordination and management institutions to manage it. The forth one is multiple currency monetary union, which refers that firstly realizing the sub-regional monetary cooperation and then transforming to the single currency monetary union. The main forms include currency board and parallel currency system (Guo, 2007).

The dollarization in Latin American Countries is the natural extension of mighty currency and the dependency which the vulnerable economy on the mighty economy. It uses American currency and monetary policies, which is the monetary test that developing countries having a relatively close relationship to American economy. It is the unilateral conduct of the countries adopting dollarization, transferring its formulation right of monetary policies to America and allowing the Federal Reserve to heighten and turn down interest rate. There is no obligation for America to consider the specific conditions and special interests of the countries using dollar when America makes corresponding policies. Compared to the practice of European Union, European Central Bank has the obligation to consider the specific conditions and special interests of all the Eurozone participating countries when making monetary policies. In addition, the policies need to be implemented by the central bank of the participating countries.

While the African regional monetary cooperation, the regional currency system constituted of 15 less developed countries, has its own historic characteristic and is the only one regional currency system which consists of countries with different economic development, as well as the result of the cooperation between the developed country and developing countries. In the colonial period, in order for better governing and convenience, France made common monetary system arrangement in its original colonies. 
In regard to the currency area, the theory of optimum currency area is regarded as the basic theory. And it gives comprehensive criteria to analysis the construction of an optimum currency area. It was considered when the European monetary integration was going to be constructed.

2) The theory of Optimum Currency Area and Criteria

The theory of Optimum Currency Area (hereinafter referred to as OCA) pioneered by Mundell in 1961 was further complemented by McKinnon and again by Kenen. The theory addresses the question of under which circumstances a country benefits from membership in a currency union. According to the OCA theory, a country that considers membership in a currency union has to balance the economic stability loss (i.e. losing national monetary policy) against the monetary efficiency gain (i.e. a competitive gain due to a decline in the general price level, stimulated aggregate demand and enhanced exports) of a single currency (Jager \& Hafner, 2013).

In economics, an OCA is a geographical region in which it would maximize economic efficiency to have the entire region share a single currency. It describes the optimal characteristics for the merger of currencies or the creation of a new currency. The theory is used often to argue whether or not a certain region is ready to become a currency union, one of the final stages in economic integration.

The judgement standard of OCA needs comprehensive analysis rather than being measured by only single factor. The OCA theory can be viewed as a tool for finding an answer to the question on how to choose the optimum exchange rate regime. It should be mentioned, however, that there is no widely accepted algorithm or index to indicate unambiguously should a country join a currency area or not (Broz, 2005).

Mundell put forward the factors highly liquidity as the criteria of optimum currency. To him if the liquidity of production criteria between two districts is high, the economic impact can be eliminated through the liquidity of factors rather than exchange rate, which can make it much easier to form a currency integration. Whereas if the liquidity of factors between two districts is low, currency integration cannot be constructed and exchange rate should be adopted to eliminate economic impact. Based on the analysis of Mundell, Mckinnon come to the conclusion that the higher economic openness the economic entity has, the more suitable to construct a relatively closed currency area through the analysis on the different effects that exchange rate fluctuations make on small state open economy and big state open economy (Snaith, 2014). Mckinnon insists that it is an 'area within which monetary-fiscal policy and flexible external exchange rates can be used to give the best resolution of three objectives' (full employment, balance of payments and low inflation) (McKinnon, 1963).

Kenen put forward the product diversification level as the criteria of optimum currency. To him the country which has lower product diversification should adopt floating exchange rate to form independent currency. While pegged exchange rate should be adopted to form currency integration area within the 
states which have high level of product diversification. The exports of a country which has low product diversification are limited. If the demands of some exports declines, the exchange rate will change substantially to maintain the original level of employment. If pegged exchange rate is adopted in certain region, it's unable to use flexible solution to adjust the exchange rate. In addition, the OCA is interpreted through single standard in the theories such as international financial highly integration, low degree of product diversification, policy integration and inflation preferences similarity theory. To J. D. Hansen and J, U. M. Nielson, the realization of currency union depends on the frequency and characteristic of exogenous shocks, internal economic structures, industrial structures and labor mobility of member states. S.S. Rehman concluded five criteria: liquidity of labor and capital, economic openness, price flexibility, commodity market integration and fiscal integration (Peng, Liu, \& Chen, 2006).

The sudden crisis in early 2010, however, cast serious doubts on European Monetary Union's viability, exposing the unsatisfactory state of the subject. Paradoxically, before the outbreak of the crisis, the theory of OCA was blamed for failing to predict the euro's success, whereas afterward it was invoked to explain the euro's bleak prospects (Cesarano, 2013).

\subsection{The Analysis of the Current Models}

The formations of the African monetary unions have their own historic reasons for their colonization to the specified countries. In the African Franc Zone, there are fifteen African countries which are former French colonies and two sub-regional monetary unions as West African Monetary Union and Central African economic and monetary community. Assessing integration projects for the East African Community, Southern African Development Community and the Economic Community of West African States, they concluded that, in spite of the potential benefits of monetary integration in terms of institutional credibility and fiscal discipline, in most cases such benefits would be inferior to the costs of being unable to stabilize specific shocks with domestic policy instruments and similar to what could be achieved with domestic reforms. Overall, the information provided by the OCA indicates suggests that the COMESA group has yet to be well suited for monetary integration. Some of its members are already quite integrated, but the whole set is heterogeneous, with various countries closer to third countries (with which, in some cases, they share membership in other communities) than to their COMESA counterparts (Vieira \& Vieira, 2013).

The European Monetary Union is the model of international currency cooperation after the collapse of the Bretton Woods System. The monetary integration of the European Union is along with the economic integration, meanwhile, its legal and political integrations are steadily forward with the sign of the European integration, "one market, one currency and one legal system". When the Euro was launched in 1999, there were 15 members in the European Union, 11 of which adopted the single currency. A common market with free flow on the 
goods, services, personnel and capital were established. Now there are 28 members and the Common Market is extending gradually.

The success of European Monetary Integration is not only the success of economic and monetary cooperation, but also the success of political cooperation, which to some extent reflecting the political willing of each member. According to the OCA theory, the opinion on whether the European Currency Union satisfies the criteria varies, along with other questions like asymmetry problem, fiscal problem and banking problem (Frankel, 2015).

European Central Bank is the highest monetary authority and is responsible for making the unified monetary standards and conditions. The central banks of the members are responsible for the execution of monetary policies in Euro zone and shall be supervised by the European Central Bank. European Central Bank, a supranational institution, is an important guarantee to the accurate monetary policies. Firstly, ensure the effectiveness of the monetary policies, which can ensure the stability of the price of commodities and strengthen the public's confidence to the European Central Bank. Secondly, make the monetary policies free to the public, which can ensure that the public can get a better understand of and make a good judgment on European Central Bank's decision making. Thirdly, monetary policies shall have independence and shall not be affected by the political pressure of European Union and the National Banks of the member states. ${ }^{6}$ Nowadays, the European Commission has realized that alongside Banking Union, launching the Capital Markets Union must be seen as a priority. This applies to all $28 \mathrm{EU}$ Member States, but it is particularly relevant to the euro area.

After years of development, European Currency Union, which was regarded as a success at first, has suffered a lot. Some scholars hold the view that the strong member states of the European Currency Union are hostages of the financially distressed member states, i.e. the strong member states have to provide financial support to the distressed states in order to preserve the European Currency Union. So a well designed and enforced legal system for the economic functioning of a union is important to reduce the uncertainty about the existence of claims (Franke, 2012). One of the main lessons of the crisis has been that fiscal policies are a matter of vital common interest in a Monetary Union. Unsustainable fiscal policies not only endanger price stability in the Union, they also harm financial stability insofar as they create contagion between Member States and financial fragmentation (European Commission, 2015).

\section{How to Construct the Legal Mechanisms of CMU?}

Although China is a unified country, four different kinds of currencies are used in the Four Regions of China, which is different from the practice of the Euro-

\footnotetext{
${ }^{6}$ European Central Bank: Guideline (EU) 2015/732 of the European Central Bank. (5) To ensure the equal treatment of counterparties, as well as to enhance operational efficiency and transparency, assets must fulfil certain uniform criteria across the Member States whose currency is the euro in order to be eligible as collateral for Euro system credit operations.
} 
pean Union. The realization of constructing the Chinese Monetary Union in the Four Regions of China is the necessity of economic development, but the monetary integration process is a long-term system design, which cannot be achieved overnight. Monetary cooperation is a key area in the cooperation of the Four Regions. If reasonable and feasible monetary cooperation plan is lack, monetary cooperation concept can only become a mere formality and cannot be used in the guidance. The monetary integration in European Union is of great significance to the practice in China. However, there are great differences in the economic circumstance, we should make monetary integration strategy according to the national conditions of China.

\subsection{Strategic Planning}

1) Monetary integration between Hong Kong and Macao

Hong Kong and Macao are both Special Administrative Regions in China, they are similar in political, economic, and social system, as well as in the economic development and structure. Compared with the other areas, the Per Capita GDP in these two areas are much similar. Hong Kong and Macao are both free trade port, where there is no limit on the flow of capital and goods. They have a strong relationship in finance and high degree of the movement of production factors. They have similar economic openness and financial policies. What's more, they have close geographical location which makes their economic relation particularly close to each other. The exchange rate policy executed in Macao is Hong Kong dollar pegged virtually. Hong Kong dollar can flow freely and its circulation volume is quite huge in Macao. All of these conditions make it feasible to construct an optimum currency area.

2) Monetary integration between Hong Kong, Macao and Mainland China

The economic development of the coastal areas of east Mainland China, especially Guangdong, has slight difference with Hong Kong and Macao. "Agreement between the Mainland and Hong Kong Closer Economic Partnership Arrangement" was signed between Mainland China and Hong Kong in 2003. Then similar agreement was signed with Macao too, which has promoted the integration and correlative dependence between Mainland China and Hong Kong, Macao and has also laid an important foundation for the financial and monetary cooperation within these regions.

With the development of Mainland China, its economic openness gets higher and higher and has received the comparable level with Hong Kong and Macao. Meanwhile, the economies in Hong Kong and Macao have much economic dependence on Mainland China, which makes it an important factor for them to make more cooperation. When certain conditions (as after the monetary integration between Hong Kong and Macao) are satisfied, appropriate currency can be chose to circulate within these three Regions.

3) Monetary integration within the Four Regions

The Four Regions in China shall move forward to create and perfect the economic and non-economic conditions in order to realize the monetary integra- 
tion within the Four Regions. Taiwan has high per capita GDP and is an open economic area. Its economy depends much on Hong Kong, Macao and Mainland China and if the above areas reach monetary integration, it will give much pressure on Taiwan to join this monetary integration. Taiwan has the qualification to join the monetary union while there is a long way to realize is just because of some political reasons. So, positive actions shall be taken in order to deal with the main obstacles, for example, promoting to construct the free trade zone with Taiwan to realize mutual benefits and complementary advantages. When the integrated market is formed, monetary integration shall be constructed.

\subsection{Construction of Specific System}

1) Construction of Economic System

1) To develop the offshore RMB market

Hong Kong Monetary Authority announced on November 12th, 2014 that the RMB conversion limit for Hong Kong residents of 20,000 yuan (RMB) per day will no longer be applicable with effect from 17 November 2014. Under the new arrangement, banks will square their positions arising from RMB conversions conducted with Hong Kong residents in the offshore market instead of the onshore market. As a result, the prevailing conversion and other relevant restrictions for onshore conversion will hence be no longer applicable (Chan 2014). Now Hong Kong residents' deposit is about 300 billion RMB while the demands for Hong Kong residents to use RMB as daily delivery is not so huge. After the conversion restriction is loosen up, the transactions on RMB will increase. After the launch of Shanghai-Hong Kong Stock Connect, investor get one more investment approach, allowing overseas investors to invest in the Mainland A-share market through Hong Kong, and Mainland investors to trade Hong Kong shares through Shanghai, which will increase the demand for conversion. From 10 November, 2015 the HKMA is offering intraday RMB funds of up to RMB10 billion to authorized institutions participating in RMB business in Hong Kong (HKMA 2014). It will also promote the market to create much more RMB financing products and promote the RMB transaction to a new level, anticipating that RMB deposit will have a moderate growth in the future.

Hong Kong shall be constructed into an offshore RMB center as soon as possible, realizing the freely conversion of RMB under the capital account. The launch of RMB business of Hong Kong banks has promoted the economic integration between Mainland China and Hong Kong, which will also promote the economic recovery of Hong Kong, enhance Hong Kong's status as an international financial center and accelerate the currency integration process.

2) To construct Chinese currency fund

Chinese currency fund shall be founded within the Four Regions as a permanent institution whose function is to be the lender of last resort for the international payment deficit of the economic entities within the region to provide and 
manage the regional aid funds, to coordinate and manage the rescue operations on crisis, to provide material guarantee for establishing and maintaining the flexible and stable exchange rate cooperation system, to do research and analysis to offer consulting suggestion fit in with the regional practice for regional economic and financial development (Bi, 2005).

3) Exchange rate adjustment mechanism

It is necessary to establish an effective exchange rate adjustment mechanism during the currency cooperation process. The nominal exchange rate system arrangements in the Four Regions are different from each other, which makes it hard to realize the unified exchange rate system in the short term, so there shall be an interim period in which the previous exchange rate arrangements shall be remained in the Four Regions. Because of the overall high dependency on foreign trade in the Four Regions and strong export competitiveness within the regional economic entities, exchange rate cooperation policies shall be made in a short turn within the Four Regions. It will on one hand make it possible that the exchange rate between the currency of the region with the currency of the member country can be kept in a reasonable level and on another hand will maintain the stability of exchange rate to prevent the competitive devaluation of the regional currency.

4) Convergence access system

Convergence criteria for the economic entities to join into the integration area shall be determined to ensure the homogeneity of the economic entities in within the single monetary district. Two kinds of convergence criteria are necessary, one is to take the European Union's practice and the Maastricht Treaty for reference, nominal convergence criteria shall be set in respect of the nominal economic variables such as exchange rate, inflation rate, long-term interest rate, financial deficit and the government debt ratio. The second kind is to set practical convergence criteria in respect of the actual economic indexes such as labor productivity, per capital output, actual growth rate and unemployment rate, according to the theory of optimum currency areas. Only when both the nominal and actual economic variables of the candidate member reach the standard, can he be a member of the integration area.

It shall be regulated that some economic entities free from the single currency area temporarily are obligated to choose to join into the second exchange rate mechanism at an appropriate time. It is prevented to gain market competitiveness through currency devaluation. The exchange rate policies shall be deemed to be related to the common interests (Zhou \& Zhang, 2008).

2) Protection of the legal system

1) To strengthen the legal system on the conversion of RMB under the capital account

The level of the freely conversion of RMB to some extent determines the internationalization process of RMB. But it is risky to open capital account in order to realize the internationalization of RMB as soon as possible before the completion of reform of RMB exchange rate regime. Moderate guidance and 
control on the conversion of RMB shall be taken through legislation. It is suggested that on one hand clauses on steadily easing restrictions on cross-border capital transactions shall be added in the Administrative Regulations of the People's Republic of China on Foreign Exchange (Revised in 2008) to guide the gradual opening of security market and personal capital account such as the cross-border ETF; and on the another hand the newly opened capital account shall be supervised to control risk through actions such as quota restrictions, pilot areas restrictions, qualification requirements and account management (Zhang \& Li, 2013).

2) To improve offshore financial market legislation

Hong Kong, enjoying a high degree of freedom economic system, developed legal system, thorough financial infrastructures, effective financial regulation system and good RMB transaction foundation, shall be constructed as the RMB offshore financial center when the international flows of RMB can't be realized, which will be the inevitable choice during the initial stage of RMB internationalization. But there are no special legislation on the RMB offshore financial transaction in both Hong Kong and mainland China. Whereas, related laws and regulations shall be made according to the development model and experience characteristics of the Hong Kong RMB transactions to supervise the legal validity of the RMB transactions in the Hong Kong offshore financial market through the liquidation channels. Meanwhile, the regulatory cooperation mechanism between mainland China and Hong Kong shall be strengthened so that the regulatory authorities of both parties can master the process of the RMB transactions in time, for example, making sufficient and effective communication on major policy issues, setting up early warning mechanism, making emergency plan, strengthening supervision information exchange (Zhong, 2011).

3) To establish the legal system on the prevention from RMB cross-border flow risk

With the promotion of RMB offshore financial market and the approach of Shanghai-Hong Kong Stock Connect in order to supervise the risk of RMB cross-border flow, risk prevention system shall be set up from the following aspects: one is to set up cross-border capital flow monitoring system to make integrated supervision on both domestic currency and foreign currency in order to roundly and accurately assess the risks raised by cross-border capital flows. Another one is to take actions regarding to the particularity of RMB cross-border flow, such as to set up specific international RMB account in the bank and add it into the foreign exchange account management, to set up RMB entry and exit monitoring network to inspect the flow of goods and capital, to set up entry and exit tracking verification system on large RMB transaction, to explicitly stipulate the retention time after the arrival of short-term foreign debt funds and to strengthen the intensity of punishment on illegal access to the securities market of overseas RMB (Xiang, 2013).

4) Regional early warning system and emergency aid system 
Information communication and supervision mechanism to the financial crisis in the Four Regions of China shall be set up. a) Early warning system on the prevention from financial crisis shall be set up. Firstly, use the experience of the association of southeast Asian nations on early warning system construction to develop a crisis early warning model appropriate to China and seek the technical assistance from Asian Development Bank; Then determine the main macroeconomic indicators related to this model; At last, establish special agency to be responsible for issuing and implementing this system and inform the monitoring results of all indexes in time. b) All defects and hidden troubles within the economic entities may cause financial crisis shall be assessed. Financial regulators shall strengthen the financial supervision cooperation, especially the joint supervision on the offshore financial center and financial entities with high leverage. Special information communication and monitoring agencies shall be set up specific to private capital flow area. c) Robust code of conduct consistent with the International standard shall be promoted to improve the economic policies decision and coordination-level within the four regions.

3) Institution Structuring.

According to the Euro system, European Central Bank (herein after refers to "ECB") is an official EU institution at the heart of the Euro system and the Single Supervisory Mechanism. It is also a public institution that manages the currency of a country or group of countries and controls the money supply literally, the amount of money in circulation. The main objective of many central banks is price stability. The European System of Central Bank (herein after refers to "ESCB") comprises the ECB and the national central banks (NCBs) of all EU Member States whether they have adopted the euro or not. The Euro system comprises the ECB and the NCBs of those countries that have adopted the euro. The Euro system and the ESCB will co-exist as long as there are EU Member States outside the euro area.

The legal basis of the ECB is the Treaty Establishing the European Community $^{7}$ and Statute of the European System of Central Banks and of the European Central Bank. ${ }^{8}$ The Article 7 of the Statute of the European System of Central Banks and of the European Central Bank regulates the independence of the central bank. ${ }^{9}$ The ECB has the rights to make regulations, adopt decision and give recommendation and opinion. The national central banks have to adopt the ${ }^{7}$ See CONSOLIDATED VERSIONS OF THE TREATY ON EUROPEAN UNION AND OF THE TREATY ESTABLISHING THE EUROPEAN COMMUNITY, Official Journal of European Union (Dec. 29, 2006). http://www.ecb.europa.eu/ecb/legal/pdf/ce32120061229en00010331.pdf. ${ }^{8}$ See PROTOCOL (No 4) ON THE STATUTE OF THE EUROPEAN SYSTEM OF CENTRAL BANKS AND OF THE EUROPEAN CENTRAL BANK, Official Journal of European Union (Oct. 26, 2012). http://www.ecb.europa.eu/ecb/legal/pdf/c 32620121026en_protocol_4.pdf.

${ }^{9}$ Article 7: In accordance with Article 130 of the Treaty on the Functioning of the European Union, when exercising the powers and carrying out the tasks and duties conferred upon them by the Treaties and this Statute, neither the ECB, nor a national central bank, nor any member of their decision-making bodies shall seek or take instructions from Union institutions, bodies, offices or agencies, from any government of a Member State or from any other body. The Union institutions, bodies, offices or agencies and the governments of the Member States undertake to respect this principle and not to seek to influence the members of the decision-making bodies of the ECB or of the national central banks in the performance of their tasks. 
rules set by ECB.

Now, Mainland China, Hong Kong, Macao and Taiwan all have its own financing institution to regulate monetary matters within their respective function. The People's Bank of China is the main government authority in Mainland China. Its function is to make policies to maintain the stability of currency and banking. Hong Kong Monetary Authority is the government authority in Hong Kong responsible for maintaining monetary and banking stability. Its main functions are: maintaining currency stability within the framework of the Linked Exchange Rate system; promoting the stability and integrity of the financial system, including the banking system; helping to maintain Hong Kong's status as an international financial center, including the maintenance and development of Hong Kong's financial infrastructure; managing the Exchange Fund. Monetary Authority of Macao now supervises monetary and financial operations according to the terms established in the regulatory statutes governing each respective area. According to the Central Bank of the Republic of China (Taiwan) Act, the Bank's operational objectives include promoting financial stability, guiding sound banking operations, maintaining the stability of the internal and external value of the currency and, within the scope of the above three objectives, fostering economic development.

A unified institution has to be established to take charge of the management after the construction of Chinese monetary union. While the setting of the People's Bank of China, Hong Kong Monetary Authority, Monetary Authority of Macao and the Central Bank of the Republic of China (Taiwan) shall be remained. The unified institution has the rights to make the monetary policies and to adopt decision and give recommendation and opinion. The independence of the unified monetary institution shall be protected. When exercising the powers and carrying out the tasks and duties, it shall not be intervened.

\section{Conclusion}

Since the breakout of the Subprime Mortgage Crisis which first grew from the United States of America in late 2006, and triggered a global financial crisis to late 2008, most countries in the world have been proposing to reform the existing international currency system so that to change the dominance of US Dollar and realize the diversification of international currencies. The continuous spread of the international financial crisis has also brought great difficulties to the economies of Hong Kong, Taiwan and Macao, which are dominated by export-oriented economies. Therefore, strengthening regional financial cooperation has become an effective way to maintain financial market stability and prevent financial crisis in Hong Kong, Macao and Taiwan. But there is an obstacle to realize the regional financial cooperation, because of four currencies in the Four Regions. Although this obstacle is caused by some of historical reasons, the existence and circulation of four different currencies not only increase transaction costs, but also increase market risks, which is not conducive to the devel- 
opment of regional economy. Therefore, the implementation of monetary integration, as well as the construction of China's monetary union and its related legal system will be an essential goal and method.

Generally, similarity in economic structure, Openness and Intraregional trade, high dependence on trade, and degree of unemployment are recognized the essential evaluation points to construct a monetary union, and a study on the feasibility on construction of Chinese Monetary Union through VAR model on the data before 2008 has supported the result of feasibility. However, challenges from legal, political and economic problems still exist. For example, under the idea of "one country, two systems", Hong Kong and Macao have respectively independent currency issuance system and an independently relative regulation, and they would be a conflict between each other.

According to the theory of OCA, which was founded by Mundell and further developed by McKinnon and Kenen, a country that considers membership in a currency union has to balance the economic stability loss against the monetary efficiency gain of a single currency. As a model of successful implementation of OCA theory, the European Currency Union's system provides some useful reference for constructing the Chinese Monetary Union. In particular, the legal system of European Central Bank which ensures the effectiveness of the monetary policies, makes the monetary policies free to the public, and keeps the monetary policies independent from the political pressure of European Union and the National Banks of the member states, would be a basic legal principle to construct a unified institution and the implementing system.

The European Currency Union is of great significance to the practice in constructing the Chinese Monetary Union, however, Chinese Monetary Union cannot be realized overnight. The strategic planning should be realized step by step, from easy to difficult, and economic system should be constructed with the relevantly legal system, including to strengthen the legal system on the conversion of RMB under the capital account, improve offshore financial market legislation, establish the legal system on the prevention from RMB cross-border flow risk, and set up a regional early warning system and emergency aid system, so as to guarantee the effective operation of the Chinese Monetary Union.

\section{Acknowledgements}

This paper is funded by the 2018 China scholarship council's academic visiting program.

\section{Conflicts of Interest}

The authors declare no conflicts of interest regarding the publication of this paper.

\section{References}

Bi, Y. J. (2005). Current Situation and Approaches of the Internationalization of RMB. Journal of Shanxi Agricultural University (Social Science Edition), 2, 119-121. 
Broz, T. (2005). The Theory of Optimum Currency Areas: A Literature Review. Economic Trends and Economic Policy, 15, 53-78.

Cesarano, F. (2013). The Optimum Currency Area Puzzle. International Advances in Economic Research, 19, 259-271. https://doi.org/10.1007/s11294-013-9404-5

Chan, N. T. L. (2014). Removal of RMB Conversion Limit for Hong Kong Residents. Hong Kong: Hong Kong Monetary Authority (Nov. 12, 2014).

http://www.hkma.gov.hk/eng/key-information/speech-speakers/ntlchan/20141112-1.sh $\underline{\mathrm{tml}}$

De Grauwe, P. (1992). German Monetary Unification. European Economic Review, 36, 445-453. https://doi.org/10.1016/0014-2921(92)90101-2

European Commission (2015). The Five President's Report: Completing Europe's Economic and Monetary Union. Background Documents on Economic and Monetary Union (Jun. 22, 2015).

http://ec.europa.eu/priorities/economic-monetary-union/docs/5-presidents-report en. pdf

Franke, G. (2012). Hostages, Free Lunches and Institutional Gaps: The Case of the European Currency Union. Financial Markets and Portfolio Management, 26, 61-85. https://doi.org/10.1007/s11408-011-0176-8

Frankel, J. (2015). The Euro Crisis: Where to from Here. Journal of Policy Modeling, 37, 428-444. https://doi.org/10.1016/j.jpolmod.2015.03.006

Guo, H. (2007). Research on the Currency Cooperation in African Franc Zone. West Asia and Africa, 2, 42-46.

HKMA (2014). HKMA Welcomes Launch of Shanghai-Hong Kong Stock Connect. Hong Kong Monetary Authority (Nov. 10, 2014).

http://www.hkma.gov.hk/eng/key-information/press-releases/2014/20141110-4.shtml

Jager, J., \& Hafner, K. A. (2013). The Optimum Currency Area Theory and the EMU. Intereconomics, 48, 315-322. https://doi.org/10.1007/s10272-013-0474-7

Li, K. Q. (2015). Central Government Work Report of People's Republic of China 2015. The State Department of China. http://www.gov.cn/guowuyuan/2015-03/16/content 2835101.htm

Li, K. Q. (2016). Central Government Work Report of People's Republic of China 2016. The State Department of China. http://www.gov.cn/guowuyuan/2016-03/05/content 5049372.htm

McKinnon, R. (1963). Optimum Currency Areas. American Economic Review, 53, 717-725.

Peng, X. F., Liu, J. X., \& Chen, Z. Y. (2006). Research Summary on Chinese Monetary Integration. Academic Research, No. 3, 139-142.

Snaith, H. (2014). Narratives of Optimum Currency Area Theory and Eurozone Governance. New Political Economy, 19, 183-200. https://doi.org/10.1080/13563467.2013.779653

Vieira, C., \& Vieira, I. (2013). Monetary Integration in Eastern and Southern Africa: Choosing a Currency Peg for Comesa. South African Journal of Economics, 81, 356-372. https://doi.org/10.1111/j.1813-6982.2012.01318.x

Wang, N. (2007). An Analysis on the Construction of Chinese Yuan Area. Journal of Nanping Teachers College, 26, 94-97.

Xiang, Y. P. (2013). A Study on Legal Approaches of RMB Internationalization. Hebei Law Science, 5, 120-126. 
Xiong, Q., \& Liu, Y. Y. (2004). An Analysis on the Construction of Chinese Yuan. Productivity Research, 11, 61-63.

Yan, G. J. (2001). Foresight on the Monetary Integration within the Four Regions of China. Journal of Shanghai Finance College, 2, 11-14.

Zhang, C. Q., \& Li, J. (2013). The Study on Feasibility and Roadmap of Building Renminbi Bloc in the Four-Region across the Strait. World Economy Studies, 8, 23-28.

Zhang, Z., Sato, K., \& McAleer, M. (2008). Is Greater China a Currency Union? A Tale of the Chinese Trio. Mathematics and Computers in Simulation, 78, 319-327.

Zhong, L. (2011). Theory on Building Hong Kong's Renminbi Offshore Financial Center. Fujian Finance, 1, 22.

Zhou, N. L., \& Zhang, H. L. (2008). The Research on the Monetary Cooperation Framework and Mechanism in Four-Regions of China across the Straits. World Economy Studies, 11, 71-78.

Zhu, M. N., \& Chen, S. (2004). Constructing a "Chinese Yuan Area": Feasibility and Perspective. Journal of Xiamen University (Arts \& Social Sciences), 4, 99-106.

Zhu, X. B. (2007). The International Practice and Enlightenment of Regional Currency Cooperation. Economic Review Journal, 12, 38-40.

Zhu, X. B. (2008). Currency Cooperation Models in Africa and Their Influence. Productivity Research, 13, 45-46. 